\title{
EXAMINING WHAT BEST EXPLAINS CORPORATE CREDIT RISK: ACCOUNTING-BASED VERSUS MARKET-BASED MODELS
}

\author{
Antonio Trujillo-Ponce ${ }^{1}$, Reyes Samaniego-Medina ${ }^{2}$, \\ Clara Cardone-Riportella ${ }^{3}$ \\ ${ }^{1,2}$ Department of Financial Economics and Accounting, Pablo de Olavide University, \\ Carretera de Utrera Km 1, 41013 Seville, Spain \\ ${ }^{3}$ Department of Business Administration, Carlos III University of Madrid, \\ Calle Madrid 126, 28903 Getafe, Madrid, Spain \\ E-mails: ${ }^{1}$ atrujillo@upo.es (corresponding author); ${ }^{2}$ rsammed@upo.es; \\ ${ }^{3}$ ccardone@emp.uc3m.es
}

Received 15 May 2012; accepted 06 August 2012

\begin{abstract}
This paper uses a sample of 2,186 credit default swap spreads quoted in the European market during the period 2002-2009 to empirically analyze which model - accounting- or market-based - better explains corporate credit risk. We find little difference in the explanatory power of these two approaches. Our results indicate that a comprehensive model that combines accounting- and market-based variables is the best option to explain the credit risk, suggesting that both types of data are complementary. We also demonstrate that the explanatory power of credit risk models is particularly strong during periods of high uncertainty, such as those experienced in the recent financial crisis. Finally, the comprehensive model continues to produce the best results if the credit rating is used as the proxy for credit risk; however, accounting variables currently appear to have a more important role than market variables in determining corporate credit ratings.
\end{abstract}

Keywords: bankruptcy, credit default swaps, credit rating, credit risk, distance-to-default, European companies.

Reference to this paper should be made as follows: Trujillo-Ponce, A.; SamaniegoMedina, R.; Cardone-Riportella, C. 2014. Examining what best explains corporate credit risk: accounting-based versus market-based models, Journal of Business Economics and Management 15(2): 253-276.

JEL Classification: C52, G13, G33, M41.

\section{Introduction}

The ability of investors or potential lenders to correctly measure the credit risks of companies is an issue that has historically attracted attention in the financial literature. This desire to understand the determinants of default risk has grown in strength following the bankruptcy of Lehman Brothers in September 2008 and the 2011 sovereign debt crisis in Europe. 
The use of credit risk models has been fully established in the literature since 1966, when Beaver published his pioneering work, 'Financial ratios as predictors of failure' in Journal of Accounting Research, which served as a reference for subsequent investigations ${ }^{1}$. This univariate model was followed by a multidimensional-type model that integrates all of the relevant variables that contribute to the success or failure of a company and provides a single diagnosis or overall assessment of their creditworthiness. The two best-known multidimensional models of credit risk are Altman's Z-score model (1968) and Ohlson's O-score model (1980). These models both use information drawn from the financial statements of borrowers and are consequently known as accountingbased models.

More recently, credit risk models have used data from the capital markets in which the shares or bonds issued by the companies in question are traded. Among the models that use market data, we must highlight those based on Merton (1974), who introduced the original model that led to subsequent research on 'structural models'2. Relying on the contingent claims analysis of Black and Scholes (1973), Merton (1974) proposes considering the value of the equity as a call option on the value of the assets of the firm with a strike price equal to the face value of the firm's debt. From this perspective, the company will default if its asset value falls below a certain default boundary related to the company's outstanding debt. However, Merton's (1974) model presents certain unrealistic assumptions; in particular, it represents the liability structure of the firm as consisting only of a non-callable zero coupon bond and assumes that bankruptcy cannot be triggered before maturity. In addition, this model presumes that the absolute priority rule always holds at maturity, implying that equity holders can only obtain a positive payoff after debt holders are completely reimbursed.

Many papers have extended Merton's (1974) original model to incorporate more realistic assumptions. Black and Cox (1976) allow default to occur as soon as a firm's asset value falls below a certain threshold (i.e., at any time). Geske (1977) uses the compound option technique to value a corporation's risky coupon bonds. Anderson and Sundaresan (1996), Mella-Barral and Perraudin (1997) propose a structural model that accounts for the possibility of debt renegotiation. A number of other papers have also made more sophisticated assumptions, including Leland (1994), Longstaff and Schwartz (1995), Leland and Toft (1996), Fan and Sundaresan (2000), Collin-Dufresne and Golstein (2001). However, despite the theoretical advances of second-generation structural-form models with respect to the original Merton framework, Wei and Guo (1997) find no evidence that the Longstaff and Schwartz (1995) model produces a better empirical performance than the Merton (1974) model in the Eurodollar market.

\footnotetext{
${ }^{1}$ Very early studies on bankruptcy prediction include the work of Fitzpatrick (1932a, b, c), and Smith and Winakor (1935).

${ }^{2}$ Another market-based approach for measuring credit risk refers to the approaches that are known as reduced-form models. The reduced-form approach relies on the assumption that the credit event occurs at a completely inaccessible time and consists of modeling the conditional law of this random time. Significant studies on this topic include the works of Litterman and Iben (1991), Jarrow and Turnbull (1995), Duffie and Singleton (1999).
} 
Our paper is closely related to recent studies that have investigated whether accountingbased or market-based approaches are more appropriate for measuring corporate credit risk. Accounting models have been criticized for the historic nature of the information that they use as inputs and for not accounting for the volatility of a firm's assets during estimations of its risk of default (e.g., Vassalou, Xing 2004) ${ }^{3}$. However, the inefficiencies of capital markets may lead to prediction errors in market-based models. Hillegeist et al. (2004) conclude that a measure based on the Black-Scholes-Merton option-pricing model provides significantly more information than either of the two most popular accounting-based measures (Z-Score and O-Score). By contrast, Agarwal and Taffler (2008) conclude that although there is little difference between the predictive abilities of the accounting- and market-based approaches, the accounting-based models lead to greater bank profitability in conditions involving differential decision error costs and competitive pricing regimes. Other studies report mixed results. Demirovic and Thomas (2007) find that although distance-to-default is the most significant single variable for the measurement of corporate credit risk, market-based models exhibit better performance if accounting data are included. Tanthanongsakkun and Treepongkaruna (2008) and Das et al. (2009) reach similar conclusions.

The financial literature has used a range of metrics as proxies for credit risk. For instance, measures of credit risk that have been used by published studies include the company's financial condition (i.e., bankrupt versus non-bankrupt firms) (e.g., Altman 1968; Ohlson 1980; Hillegeist et al. 2004; Agarwal, Taffler 2008; Jakubík, Teplý 2011), the credit rating assigned to a company by a rating agency (e.g., Ang, Patel 1975; Blume et al. 1998; Demirovic, Thomas 2007), and the spreads of bonds that have been issued by the firm and listed on a secondary market (e.g., Collin-Dufresne et al. 2001; Longstaff, Rajan 2006; Wu, Zhang 2008). However, more recently, the empirical literature on credit risk has focused on credit default swap (CDS) spreads (e.g., Alexander, Kaeck 2008; Das et al. 2009; Ericsson et al. 2009; Forte, Peña 2009; Corò et al. 2013; Díaz et al. 2013).

Credit default swaps are credit protection contracts in which one party receives periodic premiums in exchange for agreeing to make a contingent payment if a defined credit event occurs ${ }^{4}$. For buyers of credit protection, the CDS market offers an opportunity to reduce credit concentration and regulatory capital while maintaining customer relationships. For sellers of protection, CDSs offer the opportunity to earn income for taking on credit exposure over a customized term without having to fund the position in question (Packer, Suthiphongchai 2003).

As Das et al. (2009) note, CDSs provide a viable alternative for measuring credit risk for several reasons. First, CDS spreads offer cross-sectional and time-series credit quality information; as a result, studies of this continuous variable contrast with studies

\footnotetext{
${ }^{3}$ This assumption does not hold for Merton's model, in which firms may have similar levels of equity and debt but very different likelihoods of default if the volatilities of their assets differ.

${ }^{4}$ The regular payment made by the CDS buyer to the CDS seller is expressed as a percentage (normally in terms of basis points) of the contract's notional value and is known as the CDS premium (or the CDS spread) (Ismailescu, Kazemi 2010).
} 
examining binary data samples of bankruptcies, which consider a company to be healthy until a default occurs. Second, CDS spreads reflect market perceptions of default rather than the perspective of a particular rating agency. Third, spreads capture both the default and the recovery risk aspects of firm distress. Finally, CDS spreads are less susceptible than corporate bond spreads to liquidity and tax effects (Elton et al. 2001). In addition, the 'price' of a CDS is normally quoted as a constant maturity spread, whereas bond spreads are calculated by subtracting an unknown risk-free interest rate from the bond yield and are therefore not directly comparable if the maturities of the underlying bonds differ (Alexander, Kaeck 2008).

This paper contributes to the literature in three ways. First, to the best of our knowledge, this study is the first to investigate whether significant differences between accountingand market-based approaches for measuring credit risk can be observed in the European market $^{5}$. Given the benefits that have been identified in the literature, we have chosen to use CDS spreads as the best proxy for credit risk. Second, although most of the extant research stops at the onset of the recession, we consider an extended time span, from 2002 to 2009, that includes both high-growth and economic crisis periods. The extension of the analysis to include the crisis period enables us to assess whether the findings reported in previous papers are robust to changes in the economic cycle. Finally, this paper evaluates the results that are obtained when credit ratings are used instead of CDS spreads as a measure for creditworthiness.

The paper is structured as follows. The next section describes the data and methodology employed in the empirical research and defines the explanatory variables. Section 2 presents and discusses the results obtained. The last section summarizes and concludes.

\section{Data and methodological aspects}

\subsection{Sample}

Our sample comprises firms listed on the FTSEuroFirst 100 Index with information about CDS spreads available in the Markit database during the period 2002-20096. Markit's CDS data do not reflect any specific trading activity; instead, these data are post-trade valuation information drawn from numerous financial institutions, including inter-dealer brokers, electronic trading platforms, major market makers and many significant buy-side firms. The data set undergoes a rigorous cleaning process in which stale, flat curves, outliers, and inconsistent data are discarded ${ }^{7}$.

As is customary, firms operating in the financial sector are excluded from the analysis of this study due to the different structure of their financial statements. Entities that present abnormal ratios or extreme values were also eliminated from the sample as outliers.

\footnotetext{
${ }^{5}$ One notable exception is Demirovic and Thomas (2007), who examine a sample of UK-listed companies over the 1990-2002 time period.

${ }^{6}$ The FTSEurofirst 100 Index includes the 60 companies with the greatest market capitalization in the FTSE Developed Europe Index and 40 additional European companies that are selected for their size and sector representation. Please see http://www.ftse.com for more details.

${ }^{7}$ Please see http://www.markit.com for a detailed description of this database.
} 
After the completion of this filtering process, the final sample consisted of 2,186 observations from 51 unique firms in six different European countries (France, Germany, Italy, the Netherlands, Spain, and the United Kingdom). Table 1 illustrates the number of observations that compose the sample, organized by year and by CDS maturity.

Table 1. Number of observations

\begin{tabular}{ccccccccc}
\hline & \multicolumn{7}{c}{ CDS maturities } \\
\hline & 1-Year & 2-Year & 3-Year & 5-Year & 10-Year & 15 -Year & 30 -Year & All maturities \\
\hline 2002 & 28 & 28 & 28 & 28 & 28 & 25 & 12 & 177 \\
\hline 2003 & 34 & 35 & 35 & 35 & 35 & 34 & 30 & 238 \\
\hline 2004 & 38 & 39 & 39 & 39 & 39 & 38 & 38 & 270 \\
\hline 2005 & 41 & 41 & 41 & 41 & 41 & 41 & 41 & 287 \\
\hline 2006 & 42 & 42 & 43 & 43 & 43 & 43 & 43 & 299 \\
\hline 2007 & 47 & 47 & 47 & 47 & 47 & 46 & 45 & 326 \\
\hline 2008 & 46 & 46 & 46 & 46 & 46 & 46 & 46 & 322 \\
\hline 2009 & 39 & 39 & 39 & 39 & 39 & 39 & 33 & 267 \\
\hline All years & 315 & 317 & 318 & 318 & 318 & 312 & 288 & 2,186 \\
\hline
\end{tabular}

In accordance with the procedures used by similar studies, we used unconsolidated statements, thus preventing relevant differences in the profit and loss statements and the balance sheets of parent companies and subsidiaries from negating each other. We obtained the accounting data from the Amadeus database, and market information was acquired from the Datastream database ${ }^{8}$.

\subsection{Definition of variables}

\subsubsection{Dependent variable}

As stated above, we use CDS spreads from the Markit database as the dependent variable. Although there exists a high concentration of CDS quotes with 5-year maturities, which has led most studies dealing with corporate credit data to focus on this one specific maturity timeframe (e.g., Longstaff et al. 2005), this approach only examines the credit risk effects for one single point on the CDS term structure. Therefore, to provide more detailed insight, we include the whole maturity spectrum, which ranges from 1 year to 30 years. We collect the CDS constant maturity spreads on a daily basis at the end of each year (averaged for the last 10 trading days) over the period 2002-2009. All of the examined contracts are senior unsecured obligations containing the modifiedmodified restructuring clause, which is commonly used in Europe.

We regress the natural logarithm of CDS spreads on the explanatory variables. As Aunon-Nerin et al. (2002) note, better fits are provided by regressions involving the logarithms of spreads than by direct regressions of the spreads.

\footnotetext{
${ }^{8}$ Please see http://bvdinfo.com and http://online.thomsonreuters.com/datastream for detailed information about Amadeus and Datastream, respectively.
} 
In Table 2, we present CDS spread values by maturity and year. CDS premiums vary significantly by maturity, ranging on average from 71 bps for 1-year CDS contracts to 112 bps for 30-year CDS contracts. We also observe a downward trend in premiums from 2002 to 2006 for all maturities, and the average premium reaches a minimum of 34 bps in 2006. In 2007, as a result of the onset of the financial crisis, there is a change in this trend. The worsening of the global credit crisis in 2008, which was led by, among other factors, the collapse of Lehman Brothers, dramatically increased the CDS spreads by an average of up to 298 bps. Although CDS premiums fell in 2009, they did not reach the levels that were observed prior to the start of the crisis.

Table 2. CDS spread descriptive statistics

\begin{tabular}{|c|c|c|c|c|c|c|c|c|c|}
\hline & & \multicolumn{8}{|c|}{ CDS maturities } \\
\hline & & 1-Year & 2-Year & 3-Year & 5-Year & 10-Year & 15-Year & 30-Year & $\begin{array}{c}\text { All } \\
\text { maturities }\end{array}$ \\
\hline \multirow{2}{*}{2002} & Mean & 71 & 75 & 81 & 88 & 99 & 110 & 126 & 89 \\
\hline & St. Dev. & 57 & 56 & 57 & 56 & 57 & 58 & 69 & 59 \\
\hline \multirow{2}{*}{2003} & Mean & 43 & 55 & 62 & 66 & 76 & 81 & 52 & 62 \\
\hline & St. Dev. & 132 & 172 & 184 & 162 & 154 & 156 & 21 & 149 \\
\hline \multirow{2}{*}{2004} & Mean & 15 & 22 & 30 & 45 & 66 & 70 & 74 & 46 \\
\hline & St. Dev. & 21 & 29 & 37 & 50 & 57 & 59 & 61 & 52 \\
\hline \multirow{2}{*}{2005} & Mean & 12 & 19 & 27 & 43 & 68 & 73 & 76 & 45 \\
\hline & St. Dev. & 8 & 14 & 20 & 31 & 41 & 42 & 43 & 40 \\
\hline \multirow{2}{*}{2006} & Mean & 7 & 12 & 17 & 29 & 51 & 59 & 63 & 34 \\
\hline & St. Dev. & 4 & 7 & 10 & 16 & 26 & 28 & 27 & 29 \\
\hline \multirow{2}{*}{2007} & Mean & 26 & 33 & 40 & 51 & 67 & 74 & 92 & 54 \\
\hline & St. Dev. & 13 & 14 & 16 & 18 & 22 & 23 & 44 & 32 \\
\hline \multirow{2}{*}{2008} & Mean & 323 & 328 & 319 & 299 & 274 & 271 & 274 & 298 \\
\hline & St. Dev. & 302 & 291 & 281 & 271 & 254 & 233 & 229 & 266 \\
\hline \multirow{2}{*}{2009} & Mean & 42 & 56 & 68 & 87 & 103 & 104 & 113 & 81 \\
\hline & St. Dev. & 16 & 25 & 30 & 38 & 42 & 43 & 46 & 43 \\
\hline \multirow{2}{*}{$\begin{array}{c}\text { All } \\
\text { years }\end{array}$} & Mean & 71 & 79 & 84 & 91 & 103 & 108 & 112 & 92 \\
\hline & St. Dev. & 163 & 163 & 159 & 148 & 135 & 129 & 123 & 147 \\
\hline
\end{tabular}

Note: CDS spreads are in basis points.

\subsubsection{Accounting-based independent variables}

We use 10 accounting variables to proxy for (1) liquidity, (2) capital structure, (3) debt service, (4) cash flow generation, (5) performance (profitability), and (6) firm size. All of these variables have been widely used by previous studies as drivers of credit risk, and most of these metrics are included in the two best-known accounting-based models of credit risk, namely, the Z-score (Altman 1968) and the O-score (Ohlson 1980). 
To proxy for financial liquidity, we use the ratio of current liabilities to current assets (CL/CA) and the ratio of working capital to total assets (WC/TA). The former is constructed by dividing current liabilities by current assets. One would expect that a larger ratio would indicate lower liquidity; in fact, a company with a CL/CA ratio that exceeds unity may even experience problems in meeting its short-term obligations. We thus expect a positive relationship between the CL/CA ratio and the CDS premium. The working capital to total assets ratio is a measure of the net liquid assets of the firm relative to the firm's total assets. Working capital is defined as the difference between current assets and current liabilities. In this case, we expect a negative relationship between the WC/TA ratio and the CDS premium.

We use the following two common ratios to analyze the effect of capital structure on the credit risk of companies: the ratio of retained earnings to total assets (RE/TA) and the debt-to-equity ratio (TL/Eq). Retained earnings refer to the account that reports the total amount of reinvested earnings and/or losses of a firm over its entire lifetime. The age of a firm is implicitly incorporated into this ratio; a relatively young firm will likely possess a low RE/TA ratio because it has not had time to build accumulated profit. The $\mathrm{RE} / \mathrm{TA}$ ratio also measures the leverage of a firm. Firms with high RE, relative to TA, have largely financed their assets through the retention of profits and have not greatly utilized debt. The TL/Eq ratio, also referred to as the debt-to-equity ratio, is another leverage ratio that compares a company's total liabilities with its total shareholders' equity ${ }^{9}$. A higher percentage of liabilities and a greater potential earnings variability produce a greater potential for default. Consequently, we predict opposite values for the coefficients of these ratios in the regression analysis, i.e., we predict a negative coefficient for the RE/TA ratio and a positive coefficient for the TL/Eq ratio.

Debt service is measured by the interest coverage ratio, i.e., earnings before interest and taxes (EBIT) divided by total interest payments. This ratio is used to determine how easily a company can pay the interest on its outstanding debt. In accordance with the work of Blume et al. (1998), we transform the interest coverage ratio in two ways. First, we set any negative interest coverage ratios to zero. Second, any interest coverage ratio that exceeds 100 is censored on the assumption that further increases in value convey no additional information. A lower ratio indicates that a company is burdened by debt expense to a greater degree. If a company's interest coverage ratio is 1.5 or lower, its ability to meet interest expenses may be questionable. We thus expect a negative relationship between the interest coverage ratio and the credit risk of firms.

The earnings before interest, taxes, depreciation, and amortization to total liabilities (EBITDA/TL) ratio measures a company's ability to repay debt obligations from its annualized operating cash flow. This ratio is a common metric used by credit rating agencies to assess the probability of defaulting on issued debt. A low EBITDA/TL ratio suggests that a firm may not be able to service its debt in an appropriate manner

\footnotetext{
${ }^{9}$ We decide to use the debt-to-equity ratio instead of the debt ratio (total liabilities divided by total assets) to avoid potential issues involving collinearity with the RE/TA ratio.
} 
and may result in a lowered credit rating. Conversely, a high ratio may suggest that a company may wish to consider taking on more debt and often implies that the firm in question warrants a relatively high credit rating. We hypothesize that a negative relationship exists between the EBITDA/TL ratio and the CDS premium.

To measure operating performance, we use the asset turnover ratio, which is defined as the ratio between net sales and total assets. This ratio helps measure the effectiveness with which the management uses its assets to generate sales or revenue (i.e., the productivity of a company's assets). A high asset turnover ratio is desirable because it is indicative of better operating performance. A negative relationship between the asset turnover ratio and the firm's credit risk is expected. If we use EBIT instead of net sales in the numerator of the ratio, we obtain a measure of profitability that is well known in the literature, namely, the return on total assets (ROA), which is considered to be an indicator of how effectively a company is using its assets to generate earnings before its contractual obligations must be paid. Moreover, in accordance with the customary practices of the literature (e.g., Arslan, Karan 2009), a third profitability ratio of net income divided by total assets (NI/TA) is also constructed. A negative relationship between all of these ratios and the CDS spreads is expected.

Finally, because the effect of size on firm's credit risk appears to be non-linear, we use the logarithm of firm assets to accommodate the non-linear nature of this relationship. We expect that a company with a larger quantity of assets will have a lower CDS premium.

\subsubsection{Market-based independent variables}

As stated above, the theoretical inspiration for structural approach is Merton's (1974) model. Merton (1974) considers the equity of a firm as a European-type call option on its assets, with the strike price being the accounting value of the outstanding debt due for repayment in the defined time horizon. Therefore, we can use the formulation of Black and Scholes (1973) to determine the probability that the company will default.

According to the general assumptions of the Black-Scholes-Merton model, we can relate the market value of the firm's equity at time $0, E_{0}$, with the market value of the assets, $V_{0}$, and the volatility of the return on these assets, $\sigma_{V}$, using the following known expressions of the model:

$$
\begin{aligned}
& E_{0}=V_{0} N\left(d_{1}\right)-D e^{-r T} N\left(d_{2}\right), \\
& d_{1}=\frac{\ln \left(V_{0} / D\right)+\left(r+\sigma_{V}^{2} / 2\right) T}{\sigma_{V} \sqrt{T}}, \\
& d_{2}=\frac{\ln \left(V_{0} / D\right)+\left(r-\sigma_{V}^{2} / 2\right) T}{\sigma_{V} \sqrt{T}}=d_{1}-\sigma_{V} \sqrt{T},
\end{aligned}
$$

where $N$ is the cumulative density function of the standard normal distribution, $r$ is the continuous-time risk-free interest rate, $D$ is the book value of the debt with maturity $T$, and the remaining variables are as defined above. 
It can be observed that the model has two unknowns, $V_{0}$ and $\sigma_{V}$. To estimate these parameters, we need an additional equation that relates the option's volatility to the volatility of the underlying security:

$$
\sigma_{E}=\frac{V_{0}}{E_{0}} \frac{\partial E}{\partial V} \sigma_{V} .
$$

This equation, together with the previously provided equations that are denoted by (1), makes it possible to determine $V_{0}$ and $\sigma_{V}$ through the application of a numerical algorithm that uses the values of $E_{0}$ and $\sigma_{E}$; these variables are easy to calculate for listed companies.

The risk-neutral probability that the value of the firm's assets will be less than the value of the debt on the date $T$, i.e., the probability that $V_{T}<D$, is $N\left(-d_{2}\right)$. We can also calculate the theoretical default probability by using $\mu$, the expected rate of growth in the asset value. If this expected growth rate is known, the probability that we seek, at any time $t$, is provided by the following equation:

$$
p_{t}(T)=N\left[-\frac{\ln \left(V_{t} / D\right)+\left(\mu-\frac{\sigma_{V}^{2}}{2}\right)(T-t)}{\sigma_{V} \sqrt{T-t}}\right] .
$$

After the probability of default by a firm is estimated using equation (3), it is easy to quantify the distance-to-default (DtD) for the firm in question by applying the following expression (Vassalou, Xing 2004):

$$
D t D_{t}=\frac{\ln \left(V_{t} / D\right)+\left(\mu-\frac{\sigma_{V}^{2}}{2}\right)(T-t)}{\sigma_{V} \sqrt{T-t}} .
$$

Default occurs when the ratio of the value of assets to debt is less than 1 , which implies that the logarithm of this ratio is negative. The preceding equation tells us the number of standard deviations that the logarithm of this ratio must deviate from its mean for default to occur. Because a company with a higher $D t D$ has a lower probability of insolvency (and vice versa), we expect to observe a negative relationship between this variable and the CDS spread. $D t D$ has been widely used in the literature as a marketbased variable for estimating credit risk (e.g., Demirovic, Thomas 2007; Das et al. 2009).

We make the following assumptions to obtain the $D t D$ for a firm. $E_{0}$ (the market value of equity) is considered to be the firm's market capitalization during the month of December, whereas the input $\sigma_{E}$ (the annualized standard deviation of equity returns) is estimated from the prior year of stock price returns ${ }^{10}$. We consider $t=0$ and $T=1$. In

\footnotetext{
${ }^{10} \mathrm{We}$ also consider the annualized standard deviation of equity returns $\sigma_{E}$ to be a specific independent variable. This approach allows for the effect of the equity market volatility in isolation to be assessed. Higher equity volatility often implies higher asset volatility, which would cause firm values to be more likely to fall below the default threshold (Zhang et al. 2009).
} 
accordance with previous studies (e.g., Vassalou, Xing 2004; Du, Suo 2007), we assume that $D$, the amount of debt or the default point, is equal to the book value of the current liabilities plus half of the long-term debt. We use the 1-year constant maturity Treasury rate to represent $r$, the risk-free rate. Finally, $\mu$ has little discriminating power in the Merton model and it is proxied by the GDP growth rate for next year.

In addition to the $D t D$, we consider other common market-based variables, such as the price-to-earnings $(\mathrm{P} / \mathrm{E})$ ratio, which is a measure of the price paid for a share relative to the annual net income per share. This ratio is normally used for valuation: a higher $\mathrm{P} / \mathrm{E}$ ratio indicates that investors are paying more for each unit of net income and therefore that the stock in question is more expensive than a stock with a lower $\mathrm{P} / \mathrm{E}$ ratio. We expect a negative relationship between the P/E ratio and the firm's credit risk. Similar reasoning applies to the price-to-cash flow $(\mathrm{P} / \mathrm{C})$ ratio. Finally, the price-to-book $(\mathrm{P} / \mathrm{B})$ ratio is the inverse of the known BM (book-to-market) ratio. Vassalou and Xing (2004) find that the $\mathrm{BM}$ ratio has a significant relationship with default risk; small firms with a high BM ratio tend to have a high default risk, whereas large firms with a low BM ratio are likely to have a low credit risk. Therefore, we predict a negative sign for the $\mathrm{P} / \mathrm{B}$ ratio in our equation.

\subsubsection{Control variables}

To account for country- and industry-specific effects, we include country and industry dummy variables, respectively. The country dummy variables must capture differences in factors such as the institutional framework, the degree of competition, and the accounting standards among the European countries. The industry dummies must control for differences among the industries that are considered (basic materials, consumer goods, consumer services, health care, industrials, oil and gas, utilities, and telecommunications). In addition, we include a set of year dummy variables to account for macroeconomic conditions and time-specific effects ${ }^{11}$.

Finally, we control for the maturity (in years) of the CDS contract. We hypothesize a positive relationship between the CDS maturity and the credit risk, i.e., contracts with longer maturities will tend to have higher CDS premiums.

Table 3 summarizes the explanatory variables that are considered in the present study and their expected signs.

\footnotetext{
${ }^{11}$ Because we are only interested in knowing which firm-specific variables (accounting- or marketbased) are better determinants of credit risk, we chose to include year dummies to control for all macroeconomic variables. A detailed analysis of the macroeconomic determinants of credit risk is provided by Bonfim (2009), Tang and Yan (2010).
} 
Table 3. Explanatory variables and expected signs

\begin{tabular}{llll}
\hline \multicolumn{1}{c}{ Explanatory variables } & Notation & Classification & $\begin{array}{c}\text { Expected } \\
\text { signs }\end{array}$ \\
\hline Current liabilities/Current assets & CL/CA & Liquidity & \\
\hline Working capital/Total assets & WC/TA & Liquidity & + \\
\hline Retained earnings/Total assets & RE/TA & Capital structure & - \\
\hline Total liabilities/Equity & TL/Eq & Capital structure & + \\
\hline Interest coverage ratio & Coverage & Debt service & - \\
\hline EBITDA/Total liabilities & EBITDA/TL & Cash flow generation & - \\
\hline Assets turnover ratio & Turnover & Performance (Profitability) & - \\
\hline Return on assets & ROA & Performance (Profitability) & - \\
\hline Net Income/Total assets & NI/TA & Performance (Profitability) & - \\
\hline Total assets, logarithm & Size & Size & - \\
\hline & Market-based variables & - \\
\hline Distance to default & DtD & Default risk & - \\
\hline Annualized equity volatility & $\sigma_{E}$ & Market risk & - \\
\hline Price-to-earnings ratio & P/E & Market multiple & - \\
\hline Price-to-cash flow ratio & P/C & Market multiple & - \\
\hline Price-to-book ratio & P/B & Market multiple & \\
\hline Industry, country, and year dummies & & Control variables & \\
\hline & & & \\
\hline & Control Variables & \\
\hline
\end{tabular}

\subsection{Methodology}

Following the same procedure that was used by Das et al. (2009) to examine the US market, we estimate and compare the explanatory power of the following three multivariate empirical models for the European market: (1) an accounting-based multivariate model of the determinants of credit spreads, (2) a model that uses market information, and (3) a comprehensive model that includes both accounting- and market-based data.

\subsubsection{Accounting-based model (Model 1)}

We estimate the following linear regression:

$Y_{i, t}=\alpha+\beta_{1} \cdot \mathrm{CL} / \mathrm{CA}_{i, t}+\beta_{2} \cdot \mathrm{WC} / \mathrm{TA}_{i, t}+\beta_{3} \cdot \mathrm{RE} / \mathrm{TA}_{i, t}+\beta_{4} \cdot \mathrm{TL} / \mathrm{Eq}_{i, t}+$

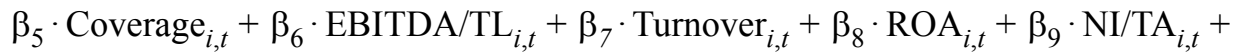
$\beta_{10} \cdot$ Size $_{i, t}+\beta_{11} \cdot$ Maturity $_{i, t}+\delta \cdot$ Industry dummies $_{i}+\gamma \cdot$ Country dummies $_{i}+$ $\theta \cdot$ Year dummies dum $_{i, t}$. 
For this regression, the subscripts $i$ and $t$ index firms and years, respectively, whereas $Y$ denotes the dependent variable, which is the natural logarithm of the CDS spread at the end of the year. As stated above, we consider 10 firm-specific accounting variables and several additional dummy variables to account for the industry, the country, and the macroeconomic environment. Finally, we control for the maturity of the CDS contract. The notations of these explanatory variables are described in Table 3 . In the regression above, $\varepsilon_{i, t}$ is the disturbance term.

\subsubsection{Market-based model (Model 2)}

We now estimate the following linear regression:

$$
\begin{aligned}
& Y_{i, t}=\alpha+\beta_{1} \cdot D t D_{i, t}+\beta_{2} \cdot \sigma_{E i, t}+\beta_{3} \cdot \mathrm{P} / \mathrm{E}_{i, t}+\beta_{4} \cdot \mathrm{P} / \mathrm{C}_{i, t}+\beta_{5} \cdot \mathrm{P} / \mathrm{B}_{i, t}+ \\
& \beta_{6} \cdot \text { Maturity }_{i, t}+\delta \cdot \text { Industry dummies }_{i}+\gamma \cdot \text { Country dummies }_{i}+ \\
& \theta \cdot \text { Year dummies }_{t}+\varepsilon_{i, t} .
\end{aligned}
$$

Again, for this regression, the subscripts $i$ and $t$ index firms and time periods, respectively, whereas $Y$ denotes the dependent variable, which is the natural logarithm of the CDS spread at the end of the year. We consider 5 firm-specific market-based variables and several dummy variables to account for the industry, the country, and the macroeconomic environment. We also control for the maturity of the CDS contract. The notations of these explanatory variables are described in Table $3 . \varepsilon_{i, t}$ is the disturbance term.

\subsubsection{Comprehensive model (Model 3)}

Finally, our third model attempts to determine whether market-based measures add any value if they are used in combination with accounting measures. Therefore, the linear regression for this model is as follows:

$$
\begin{aligned}
& Y_{i, t}=\alpha+\beta_{1} \cdot \mathrm{CL} / \mathrm{CA}_{i, t}+\beta_{2} \cdot \mathrm{WC} / \mathrm{TA}_{i, t}+\beta_{3} \cdot \mathrm{RE} / \mathrm{TA}_{i, t}+\beta_{4} \cdot \mathrm{TL} / \mathrm{Eq}_{i, t}+ \\
& \beta_{5} \cdot \text { Coverage }_{i, t}+\beta_{6} \cdot \mathrm{EBITDA} \mathrm{TL}_{i, t}+\beta_{7} \cdot \text { Turnover }_{i, t}+\beta_{8} \cdot \mathrm{ROA}_{i, t}+ \\
& \beta_{9} \cdot \mathrm{NI} / \mathrm{TA}_{i, t}+\beta_{10} \cdot \mathrm{Size}_{i, t}+\beta_{11} \cdot D t D_{i, t}+\beta_{12} \cdot \sigma_{E i, t}+\beta_{13} \cdot \mathrm{P} / \mathrm{E}_{i, t}+ \\
& \beta_{14} \cdot \mathrm{P} / \mathrm{C}_{i, t}+\beta_{15} \cdot \mathrm{P} / \mathrm{B}_{i, t}+\beta_{16} \cdot \text { Maturity }_{i, t}+\delta \cdot \text { Industry dummies }_{i}+ \\
& \gamma \cdot \text { Country dummies }_{i}+\theta \cdot \text { Year dummies }_{t}+\varepsilon_{i, t} \cdot
\end{aligned}
$$

In this regression, $Y$ once again denotes the dependent variable, which is the natural logarithm of the CDS spread for firm $i$ at the end of year $t$. Model 3 considers firmspecific accounting- and market-based variables as well as additional variables to account for the industry, the country, the macroeconomic environment, and the maturity of the CDS contract. 


\section{Results}

\subsection{Comparative analysis of credit risk models}

Table 4 reports our results for the three credit risk models that are considered ${ }^{12}$.

Table 4. Comparative analysis of credit risk models

\begin{tabular}{|c|c|c|c|}
\hline & $\begin{array}{c}\text { Model } 1 \\
\text { (Accounting-based) }\end{array}$ & $\begin{array}{c}\text { Model } 2 \\
\text { (Market-based) }\end{array}$ & $\begin{array}{c}\text { Model } 3 \\
\text { (Comprehensive) }\end{array}$ \\
\hline Intercept & $\begin{array}{c}-2.5637 * * * \\
(0.2165)\end{array}$ & $\begin{array}{c}-2.7241 * * * \\
(0.1724)\end{array}$ & $\begin{array}{c}-2.8219 * * * \\
(0.2274)\end{array}$ \\
\hline CL/CA & $\begin{array}{c}0.0246 \\
(0.0195)\end{array}$ & - & $\begin{array}{c}0.0134 \\
(0.0105)\end{array}$ \\
\hline WC/TA & $\begin{array}{c}-0.3172 * * \\
(0.1401)\end{array}$ & - & $\begin{array}{l}-0.3165^{*} \\
(0.1707)\end{array}$ \\
\hline RE/TA & $\begin{array}{c}-0.1955^{* * *} \\
(0.0424)\end{array}$ & - & $\begin{array}{c}-0.2640 * * * \\
(0.0394)\end{array}$ \\
\hline $\mathrm{TL} / \mathrm{Eq}$ & $\begin{array}{c}0.0049 * * * \\
(0.0014)\end{array}$ & - & $\begin{array}{c}0.0056^{* * * *} \\
(0.0012)\end{array}$ \\
\hline Coverage & $\begin{array}{c}-0.0107 * * * \\
(0.0030)\end{array}$ & - & $\begin{array}{c}-0.0094 * * * \\
(0.0023)\end{array}$ \\
\hline EBITDA/TL & $\begin{array}{l}-0.0496 \\
(0.2184)\end{array}$ & - & $\begin{array}{c}-0.1316 \\
(0.1738)\end{array}$ \\
\hline Turnover & $\begin{array}{l}-0.0075 \\
(0.0537)\end{array}$ & - & $\begin{array}{l}-0.0320 \\
(0.0417)\end{array}$ \\
\hline ROA & $\begin{array}{l}-0.1013 \\
(0.4628)\end{array}$ & - & $\begin{array}{l}-0.2738 \\
(0.2937)\end{array}$ \\
\hline NI/TA & $\begin{array}{c}-0.2923 * * \\
(0.1285)\end{array}$ & - & $\begin{array}{c}-0.2333^{*} \\
(0.1291)\end{array}$ \\
\hline Size & $\begin{array}{l}-0.0330 \\
(0.0411)\end{array}$ & - & $\begin{array}{l}-0.0209 \\
(0.0357)\end{array}$ \\
\hline$D t D$ & - & $\begin{array}{c}-0.0154 * * * \\
(0.0024)\end{array}$ & $\begin{array}{c}-0.0142 * * * \\
(0.0028)\end{array}$ \\
\hline$\sigma_{E}$ & - & $\begin{array}{c}0.9732 * * * \\
(0.3116)\end{array}$ & $\begin{array}{c}0.7010 * * * \\
(0.2534)\end{array}$ \\
\hline $\mathrm{P} / \mathrm{E}$ & - & $\begin{array}{c}0.0011 \\
(0.0008)\end{array}$ & $\begin{array}{l}0.0012 * \\
(0.0007)\end{array}$ \\
\hline $\mathrm{P} / \mathrm{C}$ & - & $\begin{array}{l}-0.0013 \\
(0.0009)\end{array}$ & $\begin{array}{l}-0.0008 \\
(0.0007)\end{array}$ \\
\hline
\end{tabular}

${ }^{12}$ First, however, we perform an analysis of multicollinearity for the previously selected independent variables. A study of the matrix of correlations indicates that most of the coefficients of bivariate correlation are lower than 0.65 . We subsequently confirm that collinearity would not be a problem by calculating the variance inflation factor (VIF); this factor reaches a value that is close to 1 for most of the variables. 
End of Table 4

\begin{tabular}{lccc}
\hline & $\begin{array}{c}\text { Model 1 } \\
\text { (Accounting-based) }\end{array}$ & $\begin{array}{c}\text { Model 2 } \\
\text { (Market-based) }\end{array}$ & $\begin{array}{c}\text { Model 3 } \\
\text { (Comprehensive) }\end{array}$ \\
\hline P/B & - & $\begin{array}{c}-0.0049 \\
(0.0047)\end{array}$ & $\begin{array}{c}-0.0436^{* * *} \\
(0.0080)\end{array}$ \\
\hline Maturity & $\begin{array}{c}0.0166^{* * *} \\
(0.0003)\end{array}$ & $\begin{array}{c}0.0163 * * * \\
(0.0003)\end{array}$ & $\begin{array}{c}0.0165^{* * *} \\
(0.0003)\end{array}$ \\
\hline $\begin{array}{l}\text { Industry } \\
\text { dummies }\end{array}$ & Yes & Yes & Yes \\
\hline $\begin{array}{l}\text { Country } \\
\text { dummies }\end{array}$ & Yes & Yes & Yes \\
\hline Year dummies & Yes & Yes & Yes \\
\hline Clustering level & Firm & Firm & Firm \\
\hline$N$ & 2,186 & 2,186 & 2,186 \\
\hline$R^{2}$ & $67.42 \%$ & $68.41 \%$ & $72.76 \%$ \\
\hline Adjusted $R^{2}$ & $66.97 \%$ & $68.04 \%$ & $72.32 \%$ \\
\hline
\end{tabular}

Notes: This table reports linear regressions of the logarithm of CDS spreads to accounting measures (Model 1), market-based measures (Model 2) and both (Model 3). See Table 3 for a description of the variables. Robust standard errors, which are clustered by firms, are reported in parentheses. Significance levels are indicated as follows: $* * *$ - significant at the $1 \%$ level, $* *$ - significant at the $5 \%$ level, and * - significant at the $10 \%$ level.

In the accounting-based equation (Model 1), we find that all of the variables that were considered have the expected sign. The WC/TA ratio demonstrates a negative and statistically significant relationship with CDS spreads, meaning that lower liquidity implies higher credit risk. In past studies (e.g., Altman 1968), this ratio has also been found to be a significant indicator of corporate problems.

The two variables that measure the effect of capital structure on credit risk (RE/TA and TL/Eq ratios) evince strong relationships with CDS spreads. Firms with higher retained earnings relative to total assets are expected to have lower credit risk levels due to their older age and lower leverage. However, a higher value of TL/Eq implies greater leverage and thus a higher probability of default. Recently, Jakubík and Teplý (2011) assess a sample of Czech firms for the period 1993-2005 and conclude that the TL/Eq ratio, along with the WC/TA ratio and the interest coverage ratio, are the most important indicators of business failure.

We demonstrate a strong negative relationship between the interest coverage ratio and CDS spreads. Therefore, the CDS premium declines as the firm's EBIT relative to its total interest payments increases. Nevertheless, we do not find the EBITDA/TL ratio to be a statistically significant driver of credit risk.

As expected, the regression coefficients indicate a negative relationship between profitability measures and corporate credit risk, although only the coefficient of the NI/TA ratio is statistically significant (at the $5 \%$ level). Finally, we do not find size to be a determinant of CDS spreads. However, because the sample is composed of large Euro- 
pean companies that are similar in size (the coefficient of variation for the size variable is only $25 \%$ ), a degree of caution should be exercised in interpreting this outcome.

Similarly to the results obtained by Das et al. (2009), the explanatory power of our accounting-based model is high, as this model accounts for $67 \%$ of the variation of CDS spreads.

In Model 2 (the market-based model), we find that both distance-to-default and the annualized standard deviation of equity returns are statistically significant (at the $1 \%$ level), and the signs of the coefficients for these variables are as predicted. In particular, a higher value of $D t D$ and a lower equity volatility imply lower credit risk. The $\mathrm{P} / \mathrm{E}$, $\mathrm{P} / \mathrm{C}$, and $\mathrm{P} / \mathrm{B}$ ratios produce no significant association with the $\mathrm{CDS}$ spreads. However, the coefficient sign of the $\mathrm{P} / \mathrm{E}$ ratio disagrees with our predictions. As Wang et al. (2011) note, the P/E ratio may have two opposite effects on CDS spreads: a high $\mathrm{P} / \mathrm{E}$ ratio implies high future asset growth, reducing the likelihood of financial distress, but high-growth firms tend to have high return volatilities, which increase credit risk. The explanatory power of this second model is slightly higher than the accounting-based model, with an adjusted $R^{2}$ value of $68 \%$ for Model 2 versus $67 \%$ for Model 1 .

Model 3 includes both accounting- and market-based variables for explaining credit risk. Most of the explanatory variables retain the same signs and statistical significances as were observed in Models 1 and 2. However, the WC/TA and the NI/TA ratio lose statistical significance relative to the results of the previous models, whereas the $\mathrm{P} / \mathrm{E}$ ratio and the $\mathrm{P} / \mathrm{B}$ ratio become statistically significant in Model 3 (at the $10 \%$ and $1 \%$ level, respectively).

The adjusted $R^{2}$ improves from $67 \%$ (Model 1) and 68\% (Model 2) to 72\%, suggesting that accounting- and market-based data are complementary. This finding is in accordance with the results of Agarwall and Taffler (2008) and Das et al. (2009) for the UK and the US markets, respectively.

\subsection{Robustness checks}

To further confirm the aforementioned findings, we conduct a number of robustness checks. First, we split the sample into two periods: a pre-crisis period (from 2002 to 2006) and a crisis period (from 2007 to 2009). Through this process, we investigate the possible impact of the recent financial crisis on our credit risk models. Although our broad results do not change (see Table 5) in that a comprehensive model using both types of variables remains the best option for measuring credit risk, we do observe certain differences between the two periods (before the crisis and during the crisis) with respect to the explanatory power of the models and the statistical significance of certain explanatory variables. In particular, we find that the explanatory power of the examined models is considerably higher during the crisis period than it was before the crisis period. We also observe that liquidity ratios appear to play an important role as determinants of default risk during periods of crisis. A similar phenomenon is observed for the $\mathrm{P} / \mathrm{C}$ ratio. In times of crisis, investors appear to positively value greater liquidity and reduce the premiums paid for eventual default among companies with better liquidity ratios. 


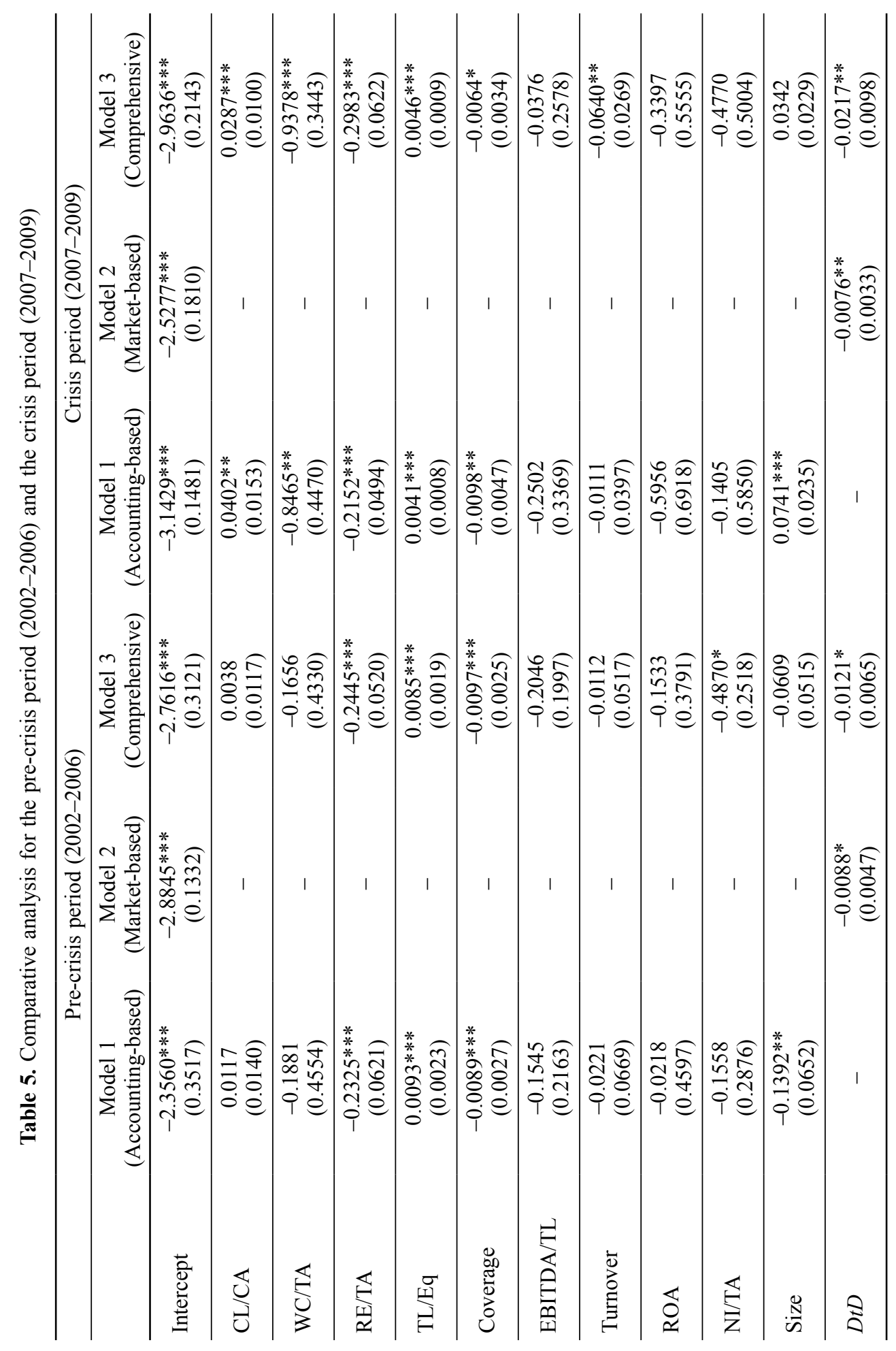




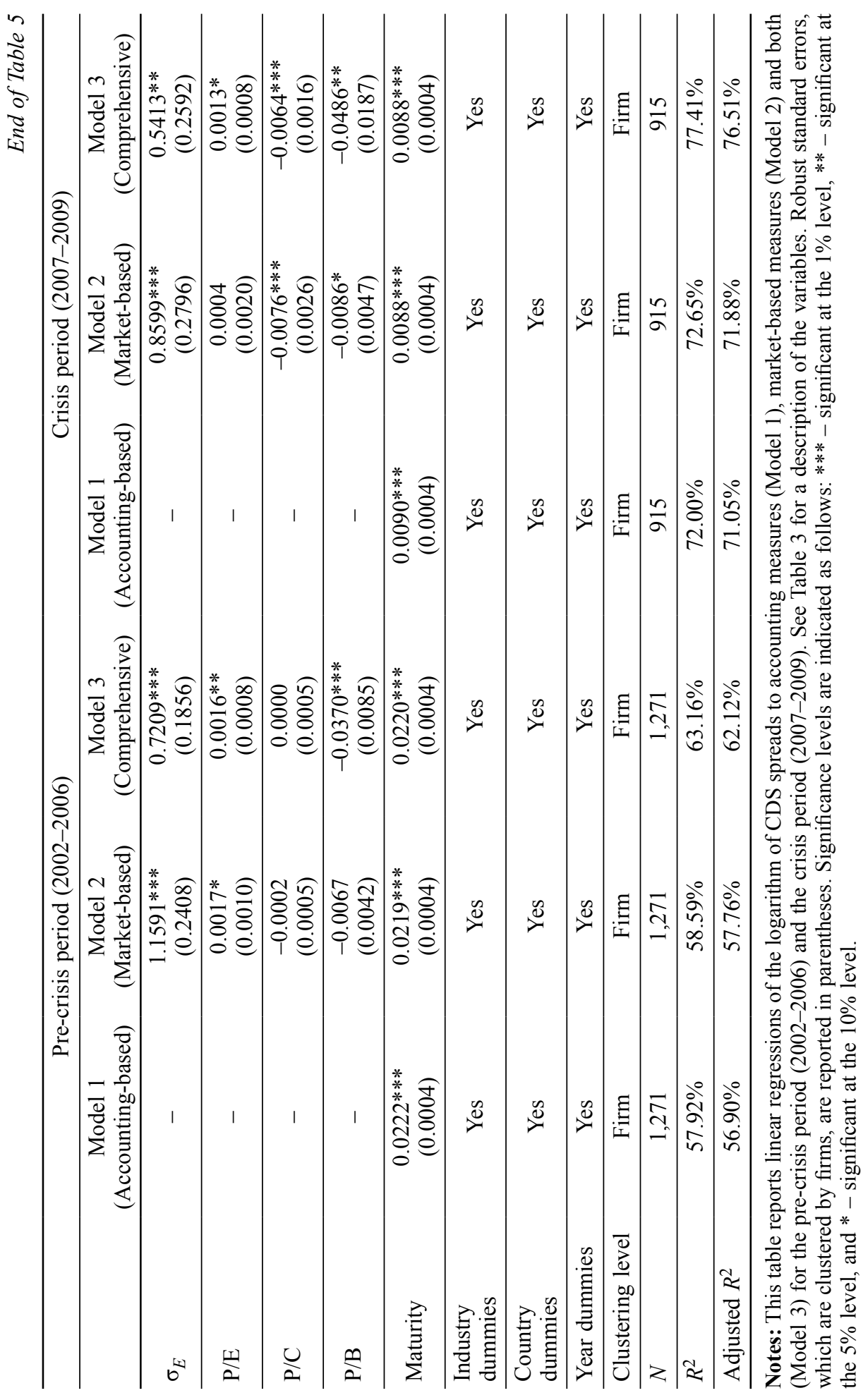


Second, we perform a robustness check to analyze the effect of the maturity of the CDS contract on our results ${ }^{13}$. We consider only 1-, 5-, and 30-year CDS spread data. Our main finding remains unchanged; that is, the comprehensive model provides the greatest explanatory power for all of the maturities that are considered.

Finally, we evaluate the method of estimation that is used in the analysis. Because panel data are used, we can re-estimate the models with either fixed or random effects. Hausman tests suggest that the fixed effects estimator is more appropriate in our case ${ }^{14}$. We now assume that the omitted variables (e.g., CDS liquidity and corporate governance, among others) may potentially correlate with the existing regressors. As expected, the comprehensive model has the greatest explanatory power.

\subsection{Are there differences if credit ratings are used instead of CDS spreads?}

Credit ratings have also been used as a typical proxy for credit risk in the literature (e.g., Demirovic, Thomas 2007). Because these credit ratings are inherently ordered, we use an ordered logistic regression for modeling the relationship between the credit risk and both the accounting and the market-based data. We use discrete values of credit ratings as a dependent variable, i.e., we convert the ratings provided by the agencies into numerical groupings that range from 1 for the best ratings to 7 for ratings of BBB- or lower. Table 6 reports the credit rating provided by the three major international rating agencies (Standard \& Poor's, Moody's and Fitch) for the firms of the sample over the 2002-2009 period as well as the assigned numerical values. Each company is assigned the rating it has at the end of the year. If the company is rated by more than one of the agencies in a single year, each rating is considered to be a separate observation. In total, we have 706 observations for 51 unique firms that are listed in the FTSEurofirst 100 index.

Our results from this analysis (see Table 7) are very similar to the results that were obtained by considering the CDS spread to be a proxy for credit risk. Again, a comprehensive model that includes both accounting and market data has the greatest explanatory power $(23 \%)$. However, our outcomes indicate that when the credit rating is used as the credit risk measure, accounting data play a more important role than market data in explaining a firm's creditworthiness (the accounting-based model explains $21 \%$ of the variability, whereas the market-based model explains only $14 \%$ of the variability). The same conclusion is reached by Demirovic and Thomas (2007) for the UK market. Finally, although most of the explanatory variables remain unaffected with respect to their signs and their levels of significance, we observe that liquidity ratios now appear to be more important drivers of default risk and that equity volatility loses much of its explanatory power. We also find that the variable that measures the effect of size on credit risk is positive and strongly statistically significant, suggesting that greater firm size is associated with a higher credit rating.

\footnotetext{
${ }^{13}$ We do not report these values due to space limitations. However, they are available upon request.

${ }^{14}$ We use only the most liquid 5-year CDS contracts to generate these results (not reported).
} 
Table 6. Credit rating conversion

\begin{tabular}{cccccc}
\hline \multicolumn{7}{c}{ Rating } & & & \\
\hline Standard \& Poor's & Moody's & Fitch & $\begin{array}{c}\text { Assigned } \\
\text { value }\end{array}$ & $\begin{array}{c}\text { No. of } \\
\text { observations }\end{array}$ & Percentage \\
\hline AAA & Aaa & AAA & 1 & & \\
\hline AA+ & Aa1 & AA+ & 1 & & \\
\hline AA & Aa2 & AA & 1 & 66 & $9.35 \%$ \\
\hline AA- & Aa3 & AA- & 1 & 109 & $15.44 \%$ \\
\hline A+ & A1 & A+ & 2 & 62 & $8.78 \%$ \\
\hline A & A2 & A & 3 & 152 & $21.53 \%$ \\
\hline A- & A3 & A- & 4 & 224 & $31.73 \%$ \\
\hline BBB+ & Baa1 & BBB+ & 5 & 72 & $10.20 \%$ \\
\hline BBB & Baa2 & BBB & 6 & 21 & $2.97 \%$ \\
\hline BBB- or lower & Baa3 or lower & BBB- or lower & 7 & 706 & $100.00 \%$ \\
\hline
\end{tabular}

Note: Rating data were obtained from Bloomberg.

Table 7. Comparative analysis using credit ratings

\begin{tabular}{|c|c|c|c|}
\hline & $\begin{array}{c}\text { Model } 1 \\
\text { (Accounting-based) }\end{array}$ & $\begin{array}{c}\text { Model } 2 \\
\text { (Market-based) }\end{array}$ & $\begin{array}{c}\text { Model } 3 \\
\text { (Comprehensive) }\end{array}$ \\
\hline $\mathrm{CL} / \mathrm{CA}$ & $\begin{array}{c}0.4932 * * * \\
(0.0934)\end{array}$ & - & $\begin{array}{c}0.4406 * * * \\
(0.0963)\end{array}$ \\
\hline WC/TA & $\begin{array}{c}-4.8666^{* * *} \\
(1.4670)\end{array}$ & - & $\begin{array}{c}-4.8688^{* * *} \\
(1.5037)\end{array}$ \\
\hline RE/TA & $\begin{array}{c}-1.3507 * * \\
(0.6775)\end{array}$ & - & $\begin{array}{c}-1.8127 * * \\
(0.7924)\end{array}$ \\
\hline $\mathrm{TL} / \mathrm{Eq}$ & $\begin{array}{l}0.0181 * * \\
(0.0091)\end{array}$ & - & $\begin{array}{c}0.0126 \\
(0.0138) \\
\end{array}$ \\
\hline Coverage & $\begin{array}{c}-0.1710^{* * *} \\
(0.0294)\end{array}$ & - & $\begin{array}{c}-0.1748 * * * \\
(0.0307)\end{array}$ \\
\hline EBITDA/TL & $\begin{array}{l}-1.0279 \\
(1.4171)\end{array}$ & - & $\begin{array}{l}-0.4149 \\
(1.4367)\end{array}$ \\
\hline Turnover & $\begin{array}{c}-0.4284 * * \\
(0.1789)\end{array}$ & - & $\begin{array}{c}-0.7650 * * * \\
(0.1858)\end{array}$ \\
\hline ROA & $\begin{array}{l}-0.0079 \\
(0.0266)\end{array}$ & - & $\begin{array}{l}-0.0161 \\
(0.0277)\end{array}$ \\
\hline NI/TA & $\begin{array}{l}-2.8892 \\
(2.1684)\end{array}$ & - & $\begin{array}{l}-1.1739 \\
(2.2590)\end{array}$ \\
\hline Size & $\begin{array}{c}-1.3907 * * * \\
(0.2928)\end{array}$ & - & $\begin{array}{c}-1.4703 * * * \\
(0.3021)\end{array}$ \\
\hline$D t D$ & - & $\begin{array}{c}-0.1631 * * * \\
(0.0429)\end{array}$ & $\begin{array}{c}-0.2244 * * * \\
(0.0471)\end{array}$ \\
\hline
\end{tabular}


End of Table 7

\begin{tabular}{lccc}
\hline & $\begin{array}{c}\text { Model 1 } \\
\text { (Accounting-based) }\end{array}$ & $\begin{array}{c}\text { Model 2 } \\
\text { (Market-based) }\end{array}$ & $\begin{array}{c}\text { Model 3 } \\
\text { (Comprehensive) }\end{array}$ \\
\hline$\sigma_{E}$ & - & $\begin{array}{c}1.6225^{*} \\
(0.8855)\end{array}$ & $\begin{array}{c}1.2209 \\
(0.8798)\end{array}$ \\
\hline $\mathrm{P} / \mathrm{E}$ & - & $\begin{array}{c}0.0066 \\
(0.0058)\end{array}$ & $\begin{array}{c}-0.0062 \\
(0.0059)\end{array}$ \\
\hline $\mathrm{P} / \mathrm{C}$ & - & $\begin{array}{c}-0.0024 \\
(0.0056)\end{array}$ & $\begin{array}{c}-0.0001 \\
(0.0061)\end{array}$ \\
\hline $\mathrm{P} / \mathrm{B}$ & - & $-0.1100^{* * *}$ & $-0.1498^{* * *}$ \\
\hline Industry & $(0.0361)$ & $(0.0431)$ \\
dummies & Yes & Yes & Yes \\
\hline Country & Yes & Yes & Yes \\
\hline dummies & Yes & Yes & Yes \\
\hline Year dummies & Yes & Yes & Yes \\
\hline$N$ & 706 & 706 & 706 \\
\hline Pseudo $R^{2}$ & $20.58 \%$ & $14.45 \%$ & $22.82 \%$ \\
\hline
\end{tabular}

Note: This table reports ordered logistic regressions of the long-term credit ratings provided by the three major international rating agencies (Standard \& Poor's, Moody's and Fitch) to accounting measures (Model 1), market-based measures (Model 2) and both (Model 3). See Table 6 for the numerical values assigned to the credit ratings. See Table 3 for a description of the independent variables. Standard errors are reported in parentheses. Significance levels are indicated as follows: *** - significant at the $1 \%$ level, $* *$ - significant at the $5 \%$ level, and * - significant at the $10 \%$ level.

\section{Conclusions}

Using a sample of 2,186 credit default swap (CDS) spreads taken from the European market during the period 2002-2009, this paper empirically analyzes which model accounting- or market-based - better explains corporate credit risk.

We find little difference in the explanatory power of these two approaches. Our results indicate that a comprehensive model that combines accounting- and market-based variables is the best option to explain the credit risk, suggesting that both types of data are complementary. This finding is in accordance with the results reported by Agarwall and Taffler (2008) and Das et al. (2009) for the UK and the US markets, respectively.

We also demonstrate that the explanatory power of accounting- and market-based variables for measuring credit risk is particularly strong during periods of high uncertainty. It may occur because CDS spreads become more sensitive during periods of crisis and therefore act as better credit risk indicators.

Finally, when the credit rating is used as a proxy for credit risk, our main conclusion is unchanged, i.e., the best results are obtained through the use of a combination of accounting- and market-based data. However, our results suggest that accounting variables play a more important role than market variables in determining credit ratings. 


\section{Acknowledgments}

We would like to thank the Fundación de la Universidad de Cantabria para el Estudio y la Investigación del sector Financiero (UCEIF), the Santander Group, and the Regional Government of Andalusia (Project of Excellence P09-SEJ-4467) for their financial support. We also acknowledge the helpful comments and suggestions of Pedro Serrano (Carlos III University of Madrid, Spain) and three anonymous reviewers. The usual disclaimers apply.

\section{References}

Agarwal, V.; Taffler, R. 2008. Comparing the performance of market-based and accounting-based bankruptcy prediction models, Journal of Banking and Finance 32: 1541-1551.

http://dx.doi.org/10.1016/j.jbankfin.2007.07.014

Alexander, C.; Kaeck, A. 2008. Regime dependent determinants of credit default swap spreads, Journal of Banking and Finance 32: 1008-1021. http://dx.doi.org/10.1016/j.jbankfin.2007.08.002

Altman, E. 1968. Financial ratios, discriminant analysis and the prediction of corporate bankruptcy, Journal of Finance 23: 589-609. http://dx.doi.org/10.1111/j.1540-6261.1968.tb00843.x

Anderson, R.; Sundaresan, S. 1996. Design and valuation of debt contracts, Review of Financial Studies 9: 37-68. http://dx.doi.org/10.1093/rfs/9.1.37

Ang, J.; Patel, K. 1975. Bond rating methods: comparison and validation, Journal of Finance 30: 631-640. http://dx.doi.org/10.2307/2978740

Arslan, Ö.; Karan, M. B. 2009. Credit risks and internationalization of SMEs, Journal of Business Economics and Management 10: 361-368. http://dx.doi.org/10.3846/1611-1699.2009.10.361-368

Aunon-Nerin, D.; Cossin, D.; Hricko, T.; Huang, Z. 2002. Exploring for the determinants of credit risk in credit default swap transaction data: is fixed income markets' information sufficient to evaluate credit risk?, Working Paper. HEC-University of Lausanne and FAME.

Beaver, W. H. 1966. Financial ratios as predictors of failure, Journal of Accounting Research 4: 71-127. http://dx.doi.org/10.2307/2490171

Black, F.; Cox, J. C. 1976. Valuing corporate securities: some effects of bond indenture provisions, Journal of Finance 31: 351-367. http://dx.doi.org/10.1111/j.1540-6261.1976.tb01891.x

Black, F.; Scholes, M. 1973. The pricing of options and corporate liabilities, Journal of Political Economy 81: 399-418. http://dx.doi.org/10.1086/260062

Blume, M.; Lim, F.; MacKinlay, A. C. 1998. The declining credit quality of U.S. corporate debt: myth or reality?, Journal of Finance 53: 1389-1413. http://dx.doi.org/10.1111/0022-1082.00057

Bonfim, D. 2009. Credit risk drivers: evaluating the contribution of firm level information and of macroeconomic dynamics, Journal of Banking and Finance 33: 281-299.

http://dx.doi.org/10.1016/j.jbankfin.2008.08.006

Collin-Dufresne, P.; Goldstein, R. 2001. Do credit spreads reflect stationary leverage ratios?, Journal of Finance 56: 1929-1957. http://dx.doi.org/10.1111/0022-1082.00395

Collin-Dufresne, P.; Goldstein, R.; Spencer Martin, J. 2001. The determinants of credit spread changes, Journal of Finance 56: 2177-2207. http://dx.doi.org/10.1111/0022-1082.00402

Corò, F.; Dufour, A.; Varotto, S. 2013. Credit and liquidity components of corporate CDS spreads, Journal of Banking and Finance 37: 5511-5525. http://dx.doi.org/10.1016/j.jbankfin.2013.07.010 
Das, S.; Hanouna, P.; Sarin, A. 2009. Accounting-based versus market-based cross-sectional models of CDS spreads, Journal of Banking and Finance 33: 719-730.

http://dx.doi.org/10.1016/j.jbankfin.2008.11.003

Demirovic, A.; Thomas, D. C. 2007. The relevance of accounting data in the measurement of credit risk, The European Journal of Finance 13: 253-268.

http://dx.doi.org/10.1080/13518470601025177

Díaz, A.; Groba, J.; Serrano, P. 2013. What drives corporate default risk premia? Evidence from the CDS market, Journal of International Money and Finance 37: 529-563.

http://dx.doi.org/10.1016/j.jimonfin.2013.07.003

Du, Y.; Suo, W. 2007. Assessing credit quality from the equity market: can a structural approach forecast credit ratings?, Canadian Journal of Administrative Sciences 24: 212-228.

http://dx.doi.org/10.1002/cjas.27

Duffie, D.; Singleton, K. J. 1999. Modelling term structures of defaultable bonds, Review of Financial Studies 12: 687-720. http://dx.doi.org/10.1093/rfs/12.4.687

Elton, E. J.; Gruber, M. J.; Agrawal, D.; Mann, C. 2001. Explaining the rate spread on corporate bonds, Journal of Finance 56: 247-277. http://dx.doi.org/10.1111/0022-1082.00324

Ericsson, J.; Jacobs, K.; Oviedo-Helfenberger, R. 2009. The determinants of credit default swap premia, Journal of Financial and Quantitative Analysis 44: 109-132.

http://dx.doi.org/10.1017/S0022109009090061

Fan, H.; Sundaresan, S. 2000. Debt valuation, renegotiation and optimal dividend policy, Review of Financial Studies 13: 1057-1099. http://dx.doi.org/10.1093/rfs/13.4.1057

Fitzpatrick, P. 1932a. A comparison of ratios of successful industrial enterprises with those of failed firms, Certified Public Accountant 12(October): 598-605.

Fitzpatrick, P. 1932b. A comparison of ratios of successful industrial enterprises with those of failed firms, Certified Public Accountant 12(November): 656-662

Fitzpatrick, P. 1932c. A comparison of ratios of successful industrial enterprises with those of failed firms, Certified Public Accountant 12(December): 727-731.

Forte, S.; Peña, J. I. 2009. Credit spreads: an empirical analysis on the informational content of stocks, bonds, and CDS, Journal of Banking and Finance 33: 2013-2025.

http://dx.doi.org/10.1016/j.jbankfin.2009.04.015

Geske, R. 1977. The valuation of corporate liabilities as compound options, Journal of Financial and Quantitative Analysis 3: 541-552. http://dx.doi.org/10.2307/2330330

Hillegeist, S.; Keating, E.; Cram, D.; Lundstedt, K. 2004. Assessing the probability of bankruptcy, Review of Accounting Studies 9: 5-34. http://dx.doi.org/10.1023/B:RAST.0000013627.90884.b7

Ismailescu, I.; Kazemi, H. 2010. The reaction of emerging market credit default spreads to sovereign credit rating changes, Journal of Banking and Finance 34: 2861-2873.

http://dx.doi.org/10.1016/j.jbankfin.2010.05.014

Jakubík, P.; Teplý, P. 2011. The JT Index as an indicator of financial stability of corporate sector, Prague Economic Papers 2: 157-176.

Jarrow, R. A.; Turnbull, S. M. 1995. Pricing derivatives on financial securities subject to credit risk, Journal of Finance 50: 53-85. http://dx.doi.org/10.1111/j.1540-6261.1995.tb05167.x

Leland, H. 1994. Corporate debt value, bond covenants and optimal capital structure, Journal of Finance 49: 1213-1252. http://dx.doi.org/10.1111/j.1540-6261.1994.tb02452.x

Leland, H.; Toft, K. 1996. Optimal capital structure, endogenous bankruptcy, and the term structure of credit spreads, Journal of Finance 51: 987-1019.

http://dx.doi.org/10.1111/j.1540-6261.1996.tb02714.x 
Litterman, R. B.; Iben, T. 1991. Corporate bond valuation and the term structure of credit spreads, The Journal of Portfolio Management 17: 52-64. http://dx.doi.org/10.3905/jpm.1991.409331

Longstaff, F. A.; Mithal, S.; Neis, E. 2005. Corporate yield spreads: default risk or liquidity? New evidence from the credit default swap market, Journal of Finance 60: 2213-2253.

http://dx.doi.org/10.1111/j.1540-6261.2005.00797.x

Longstaff, F.; Rajan, A. 2006. An empirical analysis of the pricing of collateralized debt obligations, Journal of Finance 63: 529-563. http://dx.doi.org/10.1111/j.1540-6261.2008.01330.x

Longstaff, F.; Schwartz, E. 1995. Valuing risky debt: a new approach, Journal of Finance 50: 789-820. http://dx.doi.org/10.1111/j.1540-6261.1995.tb04037.x

Mella-Barral, P.; Perraudin, W. 1997. Strategic debt service, Journal of Finance 51: 531-556. http://dx.doi.org/10.1111/j.1540-6261.1997.tb04812.x

Merton, R. C. 1974. On the pricing of corporate debt: the risk structure of interest rates, Journal of Finance 29: 449-470.

Ohlson, J. 1980. Financial ratios and the probabilistic prediction of bankruptcy, Journal of Accounting Research 19: 109-131. http://dx.doi.org/10.2307/2490395

Packer, F.; Suthiphongchai, C. 2003. Sovereign credit default swaps, BIS Quarterly Review (December): 79-88.

Smith, R. F.; Winakor, A. H. 1935. Changes in the financial structure of unsuccessful corporations. Bureau of Business Research, University of Illinois, Urbana, IL.

Tang, D. Y.; Yan, H. 2010. Market conditions, default risk and credit spreads, Journal of Banking and Finance 34: 743-753. http://dx.doi.org/10.1016/j.jbankfin.2009.05.018

Tanthanongsakkun, S.; Treepongkaruna, S. 2008. Explaining credit ratings of Australian companies: an application of the Merton model, Australian Journal of Management 33: 261-275. http://dx.doi.org/10.1177/031289620803300203

Vassalou, M.; Xing, Y. 2004. Default risk in equity returns, Journal of Finance 2: 831-868. http://dx.doi.org/10.1111/j.1540-6261.2004.00650.x

Wang, H.; Zhou, H.; Zhou, Y. 2011. Credit default swap spreads and variance risk premia, Working paper. Washington, D.C.: Federal Reserve Board.

Wei, D. G.; Guo, D. 1997. Pricing risky debt: an empirical comparison of the Longstaff and Schwartz and Merton models, Journal of Fixed Income 7: 8-28.

http://dx.doi.org/10.3905/jfi.1997.408207

Wu, L.; Zhang, F. X. 2008. A no-arbitrage analysis of macroeconomic determinants of the credit spread term structure, Management Science 6: 1160-1175.

http://dx.doi.org/10.1287/mnsc.1070.0835

Zhang, B. Y.; Zhou, H.; Zhu, C. 2009. Explaining credit default swap spreads with the equity volatility and jump risks of individual firms, Review of Financial Studies 22: 5099-5131.

http://dx.doi.org/10.1093/rfs/hhp004 
Antonio TRUJILLO-PONCE is a Senior Lecturer in Finance and is currently the Director of the Master in Finance \& Banking at the Pablo de Olavide University of Seville (Spain). He has been a visiting lecturer at the Centre of Quantitative Finance in London and the Leonard N. Stern School of Business in New York, as well as other institutions. His research interests are focused on banking and finance, with a particular emphasis on credit risk management. He has published over 20 academic research articles in various journals, such as Journal of Banking and Finance, Accounting and Finance, and Spanish Journal of Finance and Accounting. He obtained his PhD from the University of Seville, Spain.

Reyes SAMANIEGO-MEDINA is a Senior Lecturer in Finance. She has been a visiting lecturer at the Leonard. N. Stern School of Business in New York and Carlos III University of Madrid, as well as other institutions. Her main research interests are focused on banking and finance, with a particular emphasis on the Basel Capital Accords. She is a reviewer for several finance and management journals. She has published academic research articles in various journals, such as Journal of Banking and Finance, Banks and Bank Systems, and Revista Europea de Dirección y Economía de la Empresa. She obtained her PhD from the University of Seville, Spain.

Clara CARDONE-RIPORTELLA is currently a Full Professor of Finance at the Pablo de Olavide University of Seville (Spain). She has been a visiting professor at Rochester University (USA), Kingston and Reading Universities (UK), and Udine (Italy), as well as other institutions. Her research interests are focused on banking and finance, with particular emphases on credit risk, relationship banking, and the financing of small and medium companies. She has published over 20 academic research articles in various journals, such as International Small Business Journal, Scandinavian Journal of Management, The Geneva Papers on Risk and Insurance, International Review of Economics and Finance, Journal of Banking and Finance, and Spanish Journal of Finance and Accounting. She obtained her PhD from the Autonomous University of Madrid, Spain. 